\title{
RESEARCH OF THE DEPLOYMENT OF TOOLS FOR DESIGN AND SIMULATIONS IN TECHNICAL EDUCATION
}

\section{Karel DVO ̌̌́AK}

Abstract: Increase of professional competencies of graduates of secondary schools and colleges of technical specialization is based on the educational methods and used didactic technologies. Knowledge of engineering issues is necessary to combine with the skills of using computer tools for design, simulations and preparation of a production technology. The presented text introduces the implementation and results of the research of mentioned application in education carried out among students of secondary schools and colleges. Research is focused on the increase of knowledge of engineering issues and skills of using engineering applications for solving of educational projects with the emphasis on the application of interdisciplinary relations of the field.

Key words: design, interdisciplinary relations, project oriented education, simulations, engineering, virtual prototype.

\section{VÝZKUM NASAZENÍ NÁSTROJŮ PRO DESIGN A SIMULACE V TECHNICKÉM VZDĚLÁVÁNÍ}

Resumé: Zvyšování odborných kompetencí absolventů středních a vyšších odborných škol technického zaměření vychází z výukových metod a použitých didaktických technologií. Znalosti strojírenské problematiky je třeba kombinovat s dovednostmi využívání počítačových nástrojů pro design, simulace a př́pravu výrobní technologie. Předložený text představuje realizaci a výsledky výzkumného šetření nasazení uvedených aplikací ve výuce, provedeného mezi žáky středních a vyšších odborných škol. Výzkum je zaměřený na zvyšování znalostí strojírenské problematiky a dovedností využivání inženýrských aplikací pro řešení výukových projektů $\mathrm{s}$ důrazem na uplatňování mezipředmětových vztahů oboru.

Kličcová slova: design, interdisciplinární vztahy, projektová výuka, simulace, strojírenství, virtuální prototyp.

\section{1 Úvod}

Rozvoj oborové didaktiky strojírenských předmětů vychází $\mathrm{z}$ výsledků a závěrů výzkumných šetření, zaměřených na využití didaktického potenciálu technologií, nasazených v průmyslovém prostředí [1]. Možnost dobrého profesního uplatnění voblasti konstrukce a technické př́pravy výroby ve strojírenských firmách je cílem výchovy žáků, budoucích absolventů technických a informačně technických oborů středních, vyšších odborných, ale i vysokých škol. Úroveň př́pravy technického personálu, zaměřené na dosažení schopností samostatného využití znalostí oboru při současném uplatnění dovedností využívání progresivních nástrojů, je často klíčová pro získávání pracovních pozic a následný profesní rozvoj. Využívání účinných nástrojů a metod ve výuce je také měřítkem kvality jednotlivých škol a celého systému didaktiky strojírenských předmětů. Výzkum, představený $\mathrm{v}$ textu, je založený na experimentu nasazení nástrojů pro počítačový design - CAD a simulace - CAE v projektově orientované výuce strojírenských předmětů. Opírá se o teoretická východiska výuky odborných strojírenských předmětů [2] a potenciál nasazení aplikovaných i obecných informačních technologií ve výuce [3]. Postupy výzkumného šetření ve školním prostředí, použité metody, struktura projektů a testů jsou založené na výzkumných šetření, provedených v průmyslovém prostředí, zaměřených na efektivitu využivání inženýrských nástrojů pro řešení reálných projektů. Závěry předloženého výzkumu ve školním prostředí lze využít pro optimalizaci didaktického systému odborných strojírenských předmětů a plánování výukových postupů na středních, vyšších odborných i vysokých školách strojírenského, informačněstrojírenského a príbuzně technicky orientovaného zaměření.

\section{Design a simulace v projektové výuce \\ Využivání didaktického potenciálu informačních technologií vychází z aktuálních trendů soudobého vzdělávání [4]. Počítačové}


aplikace pro design a simulace představují primární nástroje využívané $\mathrm{v}$ praxi pro fáze konstrukčního návrhu a technické př́ípravy produktu. Produktem může být jednotlivý díl samostatně nebo celá sestava komponent strojírenského zařízení, případně jiný typ konstrukce, např. nástroj. Komplexní využívání uvedených technologií přesahuje oblast strojírenství. Intenzivní využití lze zaznamenat např́íklad i ve stavebnictví a potenciál nasazení je i na poli prírodních věd, nebo medicíny [5]. Digitální 2D, ale především 3D modely reálných objektů, vytvořené nástroji pro design a ověřované nástroji pro simulace, představují virtuální prototypy. Pro tvorbu modelů využíváme nástroje pro design - CAD (Computer Aided Design). V současné průmyslové praxi se využívají CAD aplikace pro tvorbu 2D křivkových, nebo plošných modelů a 3D objemových těles. Trend, vycházející z rozvoje aplikací a výkonnosti běžně dostupného hardwaru, směřuje k převážnému využívání 3D systémů. Uvedená východiska ukazují potřebu nasazení 3D CAD nástrojů na všech úrovních technicky a informačně-technicky orientovaných škol.

Výpočty a funkční ověřování charakteristik navrhovaných konstrukcí se provádí prostřednictvím nástrojů pro simulace - CAE (Computer Aided Engineering). Výpočty realizované na digitálních modelech jsou založené na algoritmech metody konečných prvků - FEM (Finite Elementh Method). CAE simulace lze realizovat při dodržení určitých zásad a pravidel i bez hlubší znalosti teorie FEM, což je důležité zejména na středních školách [6].

Uvedené moduly lze mít $\mathrm{k}$ dispozici samostatně, nicméně je výhodné disponovat komplexní aplikací, ve které je integrované široké spektrum nástrojů, potřebných pro většinu fází vývoje a technické prŕpravy výroby produktu.

Pro přiblížení prostředí průmyslové praxe se ukazuje př́nos projektové výuky, založené na řešení variabilně obtížných komplexních úloh, podrobně představené $\mathrm{v}$ [7]. Dle aktuálního učebního cíle a časové dotace pro konkrétní tematický celek lze řešit např. následující typy projektů:

- Detailní návrh jedné součásti, včetně tvorby výkresové dokumentace a výrobního postupu.

- Koncepční návrh sestavy pro funkční posouzení jednotlivých dílů nebo celku.

- Detailní návrh sestavy libovolného rozsahu s detailním rozpracováním dílů, včetně pevnostních výpočtů a výkresové dokumentace.

Ve všech př́ipadech by měly být projekty navrhovány a zadávány s požadavkem zastoupení všech kroků a aktivit, vycházejících z předchozích teoretických základů studovaného oboru. Př́klad projektu, splňujícího uvedené předpoklady, je na obrázku č. 1. Na upevnění mezipředmětových vztahů a upevnění struktur vědomostí [8] v důsledku nasazení uvedených výukových metod a použití konstruktérských nástrojů je zaměřen i předložený výzkum. Zejména jde o posouzení př́nosu zvýšení a upevnění znalostí strojírenské problematiky v souvislostmi s dovednostmi používání nástrojů CAD a CAE při řešení zadaných úloh. Jedná se především o znalosti, získané v základních předmětech:

- Strojnictví.

- Strojírenská technologie.

- Tvorba technické dokumentace.

- Technická mechanika, pružnost, pevnost.

- Technologie specializace oboru.

- Práce s CAD

- Matematické a fyzikální základy, relevantní požadavkům řešených úloh.

Testy znalostí, použité ve výzkumném šetření, obsahují otázky z témat uvedených předmětů $\mathrm{v}$ souvislostech s konstruktérskými a technologickými procesy při nasazení CAx aplikací. Klíč ke kvalitativnímu posouzení finálních žákovských projektů je také vytvářen s ohledem na technickou praxí požadované struktury znalostí a vědomostí.

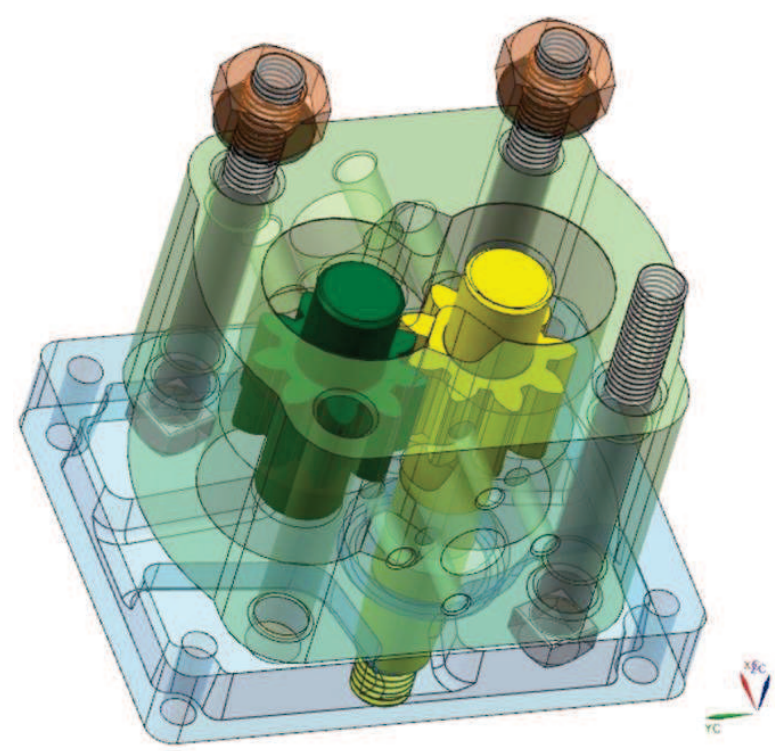


Obr. 1 - Přiklad žákovského projektu: Virtuální prototyp zubového čerpadla

\section{Cíl výzkumu, výzkumná otázka a formulace hypotéz}

Cílem realizovaného výzkumu je zvýšení efektivity výuky technického personálu využitím CAx aplikací ve výuce odborných technických, strojírensky orientovaných předmětů na středních a vyšších odborných školách.

Hlavní výzkumný problém klade otázku:

„Zvyšuje projektová výuka, podporovaná nasazením nástroju pro design a simulace znalosti a dovednosti absolventù?"

Související odvozené dílčí výzkumné otázky jsou formulovány následovně:

- Posiluje projektová výuka, podporovaná nástroji pro design a simulace, mezipředmětové vztahy oboru?

- Zvýší práce s počítačovými nástroji pro design a simulace motivaci a aktivní přistup žáků?

V dlouhodobém výzkumném šetření, realizovaném na střední průmyslové škole a vyšší odborné škole informačně-strojírenského zaměření, je uplatněn smíšený přístup, spočivající v kombinování kvalitativních a kvantitativních metod [9]. Současně s vyhodnocením testů znalostí žáků byla provedená kvalitativní analýza určitého počtu žákovských projektů, kvantifikace vybraných parametrů, jejich ohodnocení a statistické vyhodnocení.

V první fázi výzkumu byla provedena pilotáž ve výuce odborných strojírenských předmětů, základi̊ práce $\mathrm{s}$ nástroji pro design - $\mathrm{CAD}$ a výuce informačních technologií. $\mathrm{V}$ předvýzkumném experimentu byl na menším vzorku posluchačů pilotován test úrovně znalostí a dovedností. Žáci byli opakovaně rozděleni na dvě paralelní skupiny. Žákům v experimentální skupině byla v souladu s učebním plánem předmětu vysvětlena problematika tematického celku za podpory nástrojů 3D CAD. Aktivní zapojení žáků $\mathrm{v}$ této fázi bylo minimální, šlo pouze o výklad s určitou mírou interaktivity. Žáci v kontrolních skupinách absolvovali výuku „klasickou“ metodou, za podpory tištěných materiálů a výkladu bez využití počítače.

$\mathrm{Na}$ základě pilotáže a předvýzkumného experimentu byla $\mathrm{v}$ první fázi formulována hypotéza, jejíž přijetí bylo ověřené následným výzkumným šetřením:

H1: Využití počitačových aplikací pro design a simulace ve výuce strojírenských predmétů vede ke zvýšeni znalosti a dovedností absolventu pro řešení strojírenských konstrukčních úloh.

Přijetí hypotézy H1 závisí na vyhodnocení dvou faktorů - znalostí a dovedností. Vztah obou parametrů se od počátku nepotvrdil, proto byly následně formulovány dvě hypotézy:

H1: Využití počitačových aplikací pro design a simulace vprojektové výuce strojírenských predmètů vede ke zvýšeni strojirenských znalostí absolventu.

H2: Využití počítačových aplikací pro design a simulace v projektové výuce strojírenských předmětů vede ke zvýšeni dovedností absolventů pro řešení konstruktérských úloh.

\section{Výzkumná data}

Při plánování výzkumu byla po provedené rozvaze v souvislosti s předpokládanými podmínkami a po zajištění organizačních záležitostí v dlouhodobém kontextu zvolena metoda dvou paralelních skupin. Rozdělení do skupin proběhlo výběrem podle kritéria, které nesouviselo $\mathrm{s}$ řešenou problematikou. Obvykle byly skupiny vytvořené dle jejich rozdělení pro výuku cizího jazyka, nebo informačních technologií $\mathrm{v}$ rámci tř́́dy. Rozdělení do skupin bylo $\mathrm{v}$ různých trrídách kombinováno pro vyrovnání počtu $\mathrm{v}$ obou typech skupin (experimentální, kontrolní). Důležité bylo minimální ovlivnění organizačními vlivy, tzn. výuka měla být ve všech skupinách vždy rovnoměrně kontinuální. Výsledné počty žáků, rozdělných do skupin, jsou znázorněné $\mathrm{v}$ tabulce č. 1. Při daném počtu vzorků lze provést vyhodnocení $\mathrm{s}$ přijatelnou spolehlivostí pro generování závěrů. Jednou z nutných podmínek jsou stejné výchozí znalosti a dovednosti v obou skupinách. Tento požadavek byl kontrolován pretestem.

Tab. 1 - Počty vzorků ve skupinách

\begin{tabular}{|c|c|}
\hline Skupina & Počet \\
\hline Experimentální & 44 \\
\hline Kontrolní & 47 \\
\hline $\boldsymbol{\Sigma}$ & $\mathbf{9 1}$ \\
\hline
\end{tabular}

Rozdíl výstupních znalostí v obou skupinách po výukovém cyklu byl kontrolovaný posttestem. Původní test obsahoval 54 otázek a př́kladů. Ve fázi pilotáže a $\mathrm{v}$ předvýzkumu byl zredukován na 45 položek, $\mathrm{z}$ nichž 30 bylo zaměřeno na všeobecné znalosti strojírenství a 15 otázek, resp. prŕíkladů bylo orientováno na ověření dovedností. Otázky na znalosti byly sestavovány dle zkušeností z praxe a pokrývaly průřezově 
základní oblasti, se kterými se posluchači v rámci odborné praxe a čerství absolventi v praxi nejvíce setkávají. Na vypracování pretestu i posttestu znalostí byla stanovena doba 45 minut - jedna vyučovací hodina. Otázky s jednou správnou odpovědí, zaměřenou na fakta byly ohodnocené 0 , nebo 1 bodem. Součástí otázek pro posouzení dovedností byly jednoduché úlohy, řešené prostřednictvím CAx nástroje. Na vypracování testů byl stanovený čas 90 minut - dvě vyučovací hodiny. Př́klady a tvořivé odpovědi byly ohodnocené 0,1 , nebo 2 body. Celkem bylo $\mathrm{v}$ testu možné získat $0-60$ bodů, $\mathrm{z}$ toho $\mathrm{v}$ části týkající se znalostí 30 bodů a dovedností také 30 bodů. Výzkum byl zopakován ve třech cyklech při důrazu na zajištění stejných podmínek výuky i testování obou skupin. Podmínkou zahrnutí vzorku do skupiny bylo absolvování pretestu i posttestu. Žáci, kteří se zúčastnili pouze jednoho testu, byli ze statistického hodnocení vyřazeni. Jejich projekty však byly využité pro účely kvalitativního šetření dovedností práce s CAD a analýze uplatňovaných konstruktérských postupů a souvisejících procesů.

\section{Vyhodnocení výzkumu a výsledky}

Výsledky pretestů byly tabelované a vyhodnocené $\mathrm{v}$ tabulkovém procesoru MS Excel pomocí doplňku „Analýza dat“. Grafy byly generovány prostřednictvím nástroje Statistica. Průběžné výsledky $\mathrm{v}$ terénu byly ještě kontrolovány prostřednictvím statistických funkcí grafického kalkulátoru Casio. Výpočtové metody vycházely z obecných postupů zpracování statistických dat ve vztahu ke specifikům pedagogického výzkumu [10]. Vyhodnocené výsledky pretestů znalostí jsou znázorněné v tabulce č. 2. Cílem bylo porovnání výchozích parametrů kontrolní a experimentální skupiny navzájem pro potvrzení předpokladu nezávislého výběru. V této fázi testování byl uvažován předpoklad přibližně stejných znalostí strojírenské problematiky dle výše uvedených pravidel.

Pro účely kontroly a statistického vyhodnocení zvolenou metodou byla formulovaná pracovní nulová hypotéza:

H0: Znalosti posluchaču v kontrolni a experimentálni skupině jsou stejné.

oproti alternativní hypotéze:

HA: Znalosti posluchačù v kontrolní a experimentálni skupině jsou rozdilné.

Pro posouzení přijetí nulové hypotézy $H O$ oproti alternativní hypotéze $H A$ byl zvolen oboustranný t-test s hladinou významnosti 0.05 a 0,01 [11]. Stejný postup byl uplatněn i při vyhodnocení výsledků posttestu. V této fázi by přijetí alternativní hypotézy $H A$ při současné vyšší úspěšnosti experimentální skupiny znamenalo prŕímo prrijetí hypotézy $H 1$. Grafické znázornění vyhodnocení pretestů i posttestů v obou typech skupin je na grafu obrázku č. 2.

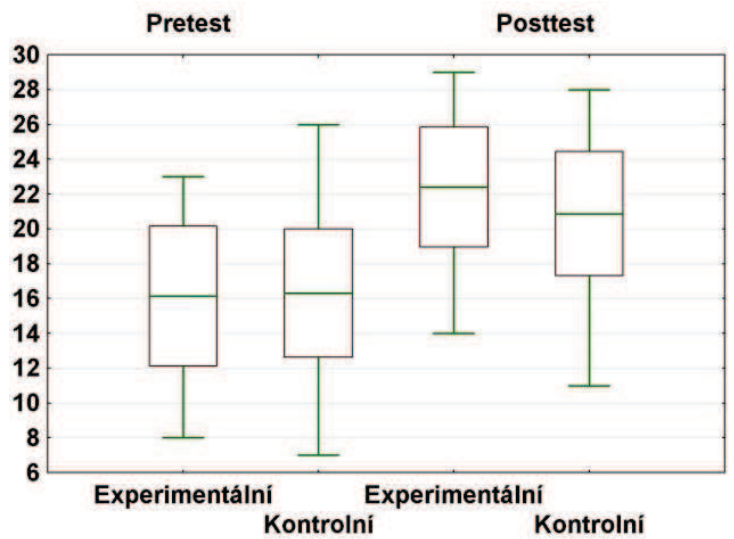

Obr. 2 - Grafické znázornění vyhodnocených dat testování znalosti strojirenské problematiky

Zpracované a tabelované výsledky pretestu a posttestu obou typů skupin jsou znázorněné v tabulkách č. 2 a 3 . Jde o souhrn zpracovaných statistických dat.

Tab. 2 - Zpracování výsledki̊ pretestu strojírenských znalostí

\begin{tabular}{|l|c|c|}
\multicolumn{2}{|c|}{ Strojirenskych znalosti } \\
\hline \multicolumn{1}{|c|}{} & Experiment. skupina & Kontrolní skupina \\
\hline Stř. hodnota & 16.136 & 16.319 \\
\hline Rozptyl & 15.800 & 13.281 \\
\hline Sm. Odch. & 4.021 & 3.684 \\
\hline Počet vzorků & 44 & 47 \\
\hline Stupnẽ volnosti & \multicolumn{2}{|c|}{87} \\
\hline t - statistika & \multicolumn{3}{|c|}{0.226} \\
\hline t - krit (0.05) & \multicolumn{2}{|c|}{1.663} \\
\hline t - krit (0.01) & \multicolumn{2}{|c|}{2.37} \\
\hline
\end{tabular}

Hodnota t-statistiky výsledků pretestu leží v oboru prrijetí hypotézy $H 0$ pro oboustranný test na hladině významnosti 0.05 . Lze príijmout hypotézu $H O$ a výchozí znalosti obou skupin považovat za stejné.

Vyhodnocení posttestu již přímo vede k přijetí, nebo zamítnutí hypotézy $H 1$. Výsledky znázorněné $v$ tabulce č. 3 byly vyhodnocené prostřednictvím jednostranného t-testu na hladině významnosti 0,05 a 0,01 .

Hodnota t-statistiky 2,088 leží v kritickém oboru přijetí na hladině významnosti 0,05 . Hypotézu $H O$ na této hladině významnosti 
zamítáme, nicméně ji lze přijmout na hladině významnosti 0,01 . Na základě statistického vyhodnocení představenou metodou nelze jednoznačně přijmout hypotézu $H 1$ o zvýšení strojírenských znalostí.

Tab. 3 - Zpracování výsledků posttestu strojirenských znalostí

\begin{tabular}{|l|c|c|}
\hline & Experiment. Skupina & Kontrolni skupina \\
\hline Stř. hodnota & 22.409 & 20.872 \\
\hline Rozptyl & 11.651 & 12.452 \\
\hline Sm. Odch. & 3.453 & 3.567 \\
\hline Počet vzorkủ & 44 & 47 \\
\hline Stupně volnosti & \multicolumn{2}{|c|}{89} \\
\hline$t$ - statistika & \multicolumn{2}{|c|}{2.088} \\
\hline$t$ - krit (0.05) & \multicolumn{3}{|c|}{1.662} \\
\hline$t$ - krit (0.01) & \multicolumn{3}{|c|}{2.368} \\
\hline
\end{tabular}

Pro pretest dovedností a aplikace vztahů byla formulována pracovní nulová hypotéza:

H0: Dovednosti řešeni strojírenských úloh jsou u posluchaču v experimentálni a kontrolní skupině stejné.

oproti alternativní hypotéze:

HA: Dovednosti řšseni strojírenských úloh jsou u posluchačů v experimentálni a kontrolni skupinè rozdillné.

Vzhledem ke stejným podmínkám získávání a vyhodnocování dat, byla zvolená metoda se stejnými parametry, jako u pretestu znalostí. Výsledky pretestu i posttestu dovedností jsou graficky znázorněné v grafu obrázku č. 3.

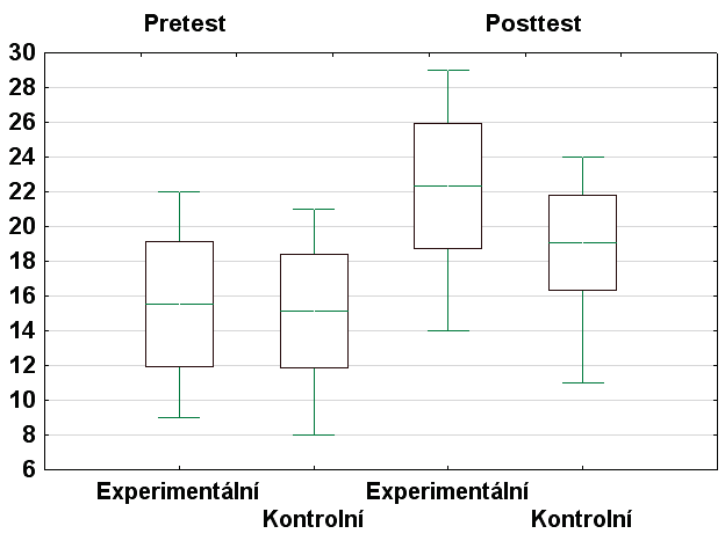

Obr. 3 - Grafické znázornění vyhodnocených dat testování dovedností řešení strojírenských úloh

Zpracované a tabelované výsledky pretestu a posttestu obou typů skupin jsou znázorněné v tabulkách č. 4 a 5.

Hodnota t-statistiky vyhodnocených výsledků pretestu leží spolehlivě v oboru přijetí nulové hypotézy na hladině významnosti 0,05 . Výchozí dovednosti skupin lze $\mathrm{v}$ této fázi považovat $\mathrm{za}$ stejné. $\quad \mathrm{Na}$ základě zpracovaných a vyhodnocených výsledků posttestu bude rozhodnuto o prijietí, nebo zamítnutí hypotézy $H 2$. Výsledky znázorněné $\mathrm{v}$ tabulce č. 4 byly vyhodnocené prostřednictvím t-testu na hladině významnosti 0,05 a 0,01 .

Hodnota t-statistiky 4.81 leží v oboru zamítnutí hypotézy $H 0$ na hladině významnosti 0,05 i 0,01 . Výsledky experimentální skupiny jsou na základě porovnání středních hodnot lepší, než výsledky v kontrolní skupině. $\mathrm{Na}$ základě výsledků šetření uvedenou metodou zamítáme pracovní hypotézu $H O$ o shodě středních hodnot ve prospěch hypotézy $H A$. Vzhledem $\mathrm{k}$ dalším posuzovaným podmínkám lze přijmout hypotézu H2 o zvýšení dovedností řešení strojírenských úloh.

Tab. 4 - Zpracováni výsledků pretestu dovedností řešeni strojírenských úloh

\begin{tabular}{|l|c|c|}
\hline & Experiment. skupina & Kontrolní skupina \\
\hline Stř. hodnota & 15.545 & 15.128 \\
\hline Rozptyı & 12.748 & 10.324 \\
\hline Sm. Odch. & 3.612 & 3.248 \\
\hline Počet vzorkủ & 44 & 47 \\
\hline Stupně volnosti & \multicolumn{2}{|c|}{86} \\
\hline t - statistika & \multicolumn{2}{|c|}{0.578} \\
\hline$t$ - krit (0.05) & \multicolumn{2}{|c|}{1.663} \\
\hline$t$ - krit (0.01) & \multicolumn{2}{|c|}{2.37} \\
\hline
\end{tabular}

Tab. 5 - Zpracování výsledků posttestu dovedností rešeni strojirenských úloh

\begin{tabular}{|l|c|c|}
\hline & Experiment. Skupina & Kontrolni skupina \\
\hline Stř. hodnota & 22.341 & 19.085 \\
\hline Rozptyl & 12.861 & 7.269 \\
\hline Sm. Odch. & 3.628 & 2.725 \\
\hline Počet vzorků & 44 & 47 \\
\hline Stupně volnosti & \multicolumn{2}{|c|}{80} \\
\hline$t$ - statistika & \multicolumn{2}{|c|}{4.81} \\
\hline$t$ - krit (0.05) & \multicolumn{2}{|c|}{1.664} \\
\hline$t$ - krit (0.01) & \multicolumn{2}{|c|}{2.374} \\
\hline
\end{tabular}

\section{Závěr}

Závěry výzkumu, provedeného představenou metodou a za uvedených podmínek dovolují přijmout hypotézu zvýšení dovedností pro řešení konstruktérských úloh. Toto tvrzení lze podpořit i zkušenostmi $\mathrm{s}$ absolventy v praxi a porovnáním dosahovaných výsledků práce na školních projektech s požadavky na výstupy práce konstruktérů. Naopak přijetí hypotézy zvýšení znalostí strojírenské problematiky je $\mathrm{v}$ této fázi stále diskutabilní. Výsledky měření dle testu toto tvrzení nepotvrzují. Důkladnou analýzou výstupů projektů bylo zjištěno, že v kontextu 
dlouhodobější práce posluchači dokážou fakta $\mathrm{v}$ př́slušných souvislostech prakticky uplatňovat. Vzhledem k metodice výzkumného šetření tento faktor podporuje přijetí hypotézy o znalostech oboru. Pedagogové mohou na základě výsledků výzkumu uplatnit vlastní tvořivost pro př́ípravu výuky dílčích témat odborných předmětů, nebo rozsáhlých dlouhodobých individuálních i týmových projektů.

Vyšší spolehlivosti výsledků, dosažených statistickým vyhodnocením by bylo možné dosáhnout větším počtem zahrnutých posluchačů, což je vzhledem k charakteru výzkumu obtížné, zejména při uvažování počtu posluchačů ve strojírenských oborech na středních školách. Naopak překážkou realizace šetření představenou metodou by neměl být použitý softwarový nástroj pro práci na projektech. Jediným předpokladem je využití 3D CAx aplikace, určené pro nasazení ve strojírenství. Určitým předpokladem pro zopakování výzkumu jsou dostatečné dovednosti pedagoga pro práci s využitým nástrojem, zejména $\mathrm{z}$ důvodu hloubkového posouzení struktury CAD a CAE dat, identifikaci a zaznamenání př́slušných parametrů. Souhrnem lze považovat projektově orientovanou výuku, podporovanou CAx aplikacemi za př́nosnou pro profesní uplatnění a další rozvoj absolventů, rozšíření kvalifikace a dovedností pedagogů a pro rozvoj oborové didaktiky strojírenských předmětů.

Příspěvek vznikl za podpory projektu specifického výzkumu PdF UHK 2012 Virtuální prototypy v projektové výuce strojírenských předmětů.

\section{Literatura}

[1] SOTÁK, J., KUNÍK, M. a SOTÁK, R. Theora and practice in the area of teaching and deployment of CAD/CAM systems. Journal of Technology and Information Education. 2011, Olomouc - EU, Univerzita Palackého, Ročník 3, Č́́slo 1, s. 49 - 54. ISSN 1803-537X (print). ISSN 1803-6805 (on-line).

[2] KROPÁČ, J., KUBÍČEK, Z., CHRÁSKA, M. a HAVELKA, M. Didaktika technických předmétù: vybrané kapitoly. 1. vyd. Olomouc, Univerzita Palackého, 2004. 223 s. ISBN 80-2440848-1.
[3] DOSTÁL, J. Výukový software a počítačové hry - nástroje moderního vzdělávání. Journal of Technology and Information Education. 2009, Olomouc - EU, Univerzita Palackého, Ročník 1, Č́́slo 1, s. 24 - 28. ISSN 1803-537X (print). ISSN 1803-6805 (on-line).

[4] DOSTÁL, J. Multimediální, hypertextové a hypermediální učební pomůcky - trend soudobého vzdělávání. Journal of Technology and Information Education. 2009, Olomouc, Vydala Univerzita Palackého, Ročník 1, Číslo 2, s. 18 - 23. ISSN 1803-6805 (on-line).

[5] STŘELEC, M. CAE technologie $v$ protetickém vývoji. Žd'ár nad Sázavou, 2010. 62 s. Absolventská práce. VOŠ a SPŠ Žd'ár nad Sázavou.

[6] SAMUEL, S., STEVENSON, B. a WEEKS, E. Advanced Simulation using Nastran: Project Oriented Learning Manual for People Who design Stuff. San Jose: Design Visionaries, 2008. ISBN 0-9754377-7-1.

[7] DVOŘÁK, K. Výuka technických předmětů, podporovaná CAx aplikacemi. Journal of Technology and Information Education. 2011, Olomouc - EU, Univerzita Palackého, Ročník 3, Číslo 2, s. 35 - 39. ISSN 1803-537X (print). ISSN 1803-6805 (on-line).

[8] MELEZINEK, A. Inženýrská pedagogika. Praha: ČVUT, 1994. ISBN 80-01-00672-4.

[9] TASHAKKORI, A. TEDDLIE, CH. Handbook of mixed methods in social and behavioral research. London: Sage, 2003. ISBN 0-7619-2073-0.

[10] CHRÁSKA, M. Metody pedagogického výzkumu. Základy kvantitativního výzkumu. Praha : Grada, 2007. ISBN 978-80-247-1369-4.

[11] NOVOVIČOVÁ, J. Pravděpodobnost a matematická statistika. Praha: ČVUT, 1999. ISBN 80-01-01980-2.

Ing. Bc. Karel Dvořák

Univerzita Hradec Králové

Pedagogická fakulta

Rokitanského 62

50003 Hradec Králové

Tel.: +420603 319305

e-mail: karel.dvorak@uhk.cz www.kdvorak.cz 